\title{
Pengembangan Lembar Kegiatan Siswa (LKS) Fisika Berbasis Inquiry Learning pada Pokok Bahasan Gerak Lurus SMA Kelas X Semester I
}

\author{
Khoirullita Yogi Wardani \\ Pendidikan Fisika Universitas Ahmad Dahlan \\ J1. Dr. Soepomo, SH., Janturan, Warungboto, Umbulharjo, Yogyakarta \\ Surat-e: khoirullitayogiwardani@gmail.com
}

\begin{abstract}
Penelitian ini bertujuan untuk merancang lembar kegiatan siswa (LKS) fisika berbasis inquiry learning, mengetahui tingkat kelayakan produk yang dikembangkan, dan mengetahui efektivitas produk terhadap keterampilan proses siswa. Jenis penelitian yang dilakukan adalah penelitian Research \& Development (R\&D) yang dikembangkan oleh Sugiono. Langkah penelitian yang diambil hanya sampai langkah ke-tujuh, yaitu I) potensi dan masalah, 2) pengumpulan data, 3) desain produk, 4) validasi desain 5) revisi desain, 6) ujicoba produk, 7) revisi produk. Hasil dari revisi produk diperoleh produk akhir. Teknik pengumpulan data berupa angket dan tes. Analisis data menggunakan analisis deskriptif kuantitatif. Produk hasil pengembangan memperoleh nilai $83,73 \%$ dengan predikat baik yang artinya produk layak digunakan oleh siswa. Dari hasil uji coba produk diperoleh nilai rata-rata klasikal pada tahap I sebesar 53,10\% dan meningkat pada tahap II sebesar 76,90\% yang artinya efektivitas lembar kegiatan siswa (LKS) fisika berbasis inquiry learning terhadap keterampilan proses siswa meningkat.
\end{abstract}

Kata kunci: Lembar Kegiatan Siswa, Inkuiry learning, Keterampilan Proses

\section{Pendahuluan}

Fisika memiliki berbagai cabang ilmu, diantaranya yaitu: mekanika, listrik dan magnet, optik, termodinamika, fisika modern dan masih banyak yang lainya. Salah satu cabang ilmu fisika yaitu mekanika. Mekanika merupakan ilmu yang mempelajari tentang gerak suatu benda. Menurut Handayani[I] materi fisika sangat kental sekali dengan gerak benda. Fisika dapat dipelajari melalui proses belajar atau pembelajaran. Belajar adalah kegiatan yang dilakukan oleh seseorang agar memiliki kompetensi berupa ketrampilan dan pengetahuan yang diperlukan[2].

Untuk mewujudkan kemampuan atau keterampilan tersebut perlu melakukan pembelajaran yang menerapkan model pembelajaran berbasis penyingkapan/penelitian (inquiry learning). Salah satu tahap perencanaan inquiry learning yaitu mengembangkan bahan - bahan belajar yang berupa contoh-contoh, ilustrasi, tugas dan sebagainya untuk dipelajari siswa, misalnya lembar kegiatan siswa (LKS)[3]. Proses pembelajaran merupakan bagian dari kegiatan pembelajaran yang harus dilaksanakan pesrta didik secara aktif.

Namun fakta yang terjadi di sekolah, pada kegiatan pembelajaran siswa masih cenderung pasif. Kegiatan pembelajaran yang ada masih terpusat pada guru. Proses pembelajaran pun belum mengarah pada penemuan. Pada awal pembelajaran siswa tidak merumuskan masalah dan dilatih mengajukan hipotesis, sehingga kegiatan pembelajaran yang dilakukan siswa tidak berangkat dari rasa ingin tahu untuk menemukan jawaban dari suatu pertanyaan. Keterampilan proses siswa tidak terlihat dalam proses pembelajaran. Keterampilan proses siswa belum dapat berkembang. Siswa hanya melakukan kegiatan pembelajaran sesuai arahan guru. Bahan ajar yang ada juga belum mengarah pada keterampilan proses siswa. Salah satu contoh bahan ajar tersebut adalah LKS, sehingga penting LKS berbasis inquiry ini dikembangkan.

\section{Kajian Pustaka}

Dari hasil penelitian yang telah dilakukan oleh Ridwan[4] dengan judul "Pengembangan LKS Gerak Lurus Berbasis Gambar Proses Untuk Pembelajaran Fisika di SMA" hasil penelitian menunjukkan bahwa nilai validitas logic LKS gerak lurus berbasis gambar proses sebesar 3,87 angka ini menunjukkan bahwa instrument ini yang cukup valid. Nilai validitas LKS gerak lurus berbasis gambar proses sebesar 3,74 pada kelas X IPA 4 dan 3,96 pada kelas X IPA 5 angka ini menunjukkan bahwa LKS gerak lurus berbasis gambar proses tergolong ke dalam kategori instrument yang cukup valid. 
Khoiriyah[5] melalui penelitian pengembanganya dengan judul "Pengembangan Bahan Ajar Lembar Kerja Siswa (LKS) Fisika Berbasis Laboratory Training Untuk Pembelajaran Fisika SMA Kelas X Semester I" hasil penelitianya yang menggunakan materi gerak lurus ini menunjukan bahwa pengembangan LKS layak digunakan berdasarkan penelitian dosen ahli materi sebesar 79,17\% dengan kualitas baik sekali, dosen ahli bahasa sebesar 93,75\% dengan kualitas sangat baik, dosen ahli media sebesar $81,25 \%$ dengan kualitas baik sekali, dan guru fisika sebesar 94,43\% dengan kualitas baik sekali. Tanggapan atau respon siswa terhadap kegiatan pembelajaran fisika dengan menggunakan LKS adalah baik sekali dengan presentase sebesar 94,05\%. Tingkat keterlaksanaan siswa dalam melakukan percobaan berkualitas baik dengan resentase nilai rata-rata $75,88 \%$.

Perbedaan penelitian yang dilakuakan Ridwan dan Khoiriyah dengan penelitian yang dilakukan ini adalah pada aspek basis penyusunannya. Pada penelitian ini peneliti mengembangkan LKS berbasis inquiry learning. LKS disusun sesuai pada tahap-tahap inquiry learning, dengan ditambahi informasi pendukung berupa materi gerak lurus yang sesuai pada masing-masing sub bab, gambar tokoh, kata-kata mutiara untuk memotivasi siswa dan evaluasi pada setiap sub babnya.

Lembar Kegiatan Siswa (LKS) merupakan panduan bagi siswa dalam memahami keterampilan proses dan konsep-konsep materi yang sedang dan akan dipelajarai[6]. Berikut adalah langkah-langkah penyusunan lembar kegiatan siswa menurut Diknas: melakukan analisis kurikulum; menyusun peta kebutuhan LKS; menentukan judul-judul LKS; penulisan LKS[3].

Kauchack dalam [6] menyatakan inkuiri merupakan salah satu cara efektif yang dapat membantu siswa meningkatkan keterampilan berpikir dengan menggunakan proses mental lebih tinggi dan keterampilan berpikir kritis. Menurut Sanjaya[7] langkah pembelajaran inkuiri secara umum yaitu sebagai berikut: orientasi; merumuskan masalah; merumuskan hipotesis; mengumpulkan data; menguji hipotesis; merumuskan kesimpulan.

\section{Metode Penelitian}

Penelitian yang dilakukan merupakan penelitian pengembangan atau Research and Development (R\&D) yaitu pengembangan bahan ajar berupa lembar kegiatan siswa (LKS) fisika berbasis inquiry learning pada pokok bahasan gerak lurus SMA kelas X semester I. Prosedur pengembangan yang digunakan adalah prosedur $R \& D$ yang dikembangkan oleh Sugiyono sampai pada langkah ketujuh yaitu revisi produk tahap II. Adapun ketujuh tahapan tersebut yaitu potensi dan masalah, pengumpulan data, desain produk, validasi produk, revisi desain, uji coba produk, revisi produk, dan hasil dari revisi diperoleh produk akhir. Pada tahap uji coba produk, teknik yang digunakan adalah teknik before-after yaitu dengan membandingkan nilai keterampilan proses siswa sebelum dan setelah menggunakan produk.

Metode yang digunakan dalam pengumpulan data yaitu angket dan tes. Sebelum soal tes diuji cobakan kepada siswa soal tersebut dicari validitas butir soal, reliabilitas, uji daya beda, dan uji taraf kesukaranya. Berikut persamaannya:

Validasi butir soal

$$
r_{x y}=\frac{N \Sigma X Y-(\Sigma X)(\Sigma Y)}{\sqrt{\left\{N \Sigma X^{2}-(\Sigma X)^{2}\right\}\left\{N \Sigma Y^{2}-(\Sigma Y)^{2}\right\}}}
$$

dengan:

$$
\begin{array}{ll}
r_{x y} & =\text { koefisien korelasi product momen } \\
\Sigma X & =\text { jumlah skor butir soal } \\
\Sigma Y & =\text { jumlah skor total } \\
\Sigma X Y & =\text { jumlah hasil kali skor butir soal } \\
N & =\text { jumlah peserta tes } \\
\Sigma X^{2} & =\text { jumlah kuadrat skor butir soal } \\
\Sigma Y^{2} & =\text { jumlah kuadrat skor total }
\end{array}
$$

Reliabilitas

$$
\begin{array}{ll}
r_{11}= & \left(\frac{n}{n-1}\right)\left(\frac{s^{2}-\sum p q}{s^{2}}\right) \\
\mathrm{r}_{\mathrm{II}} & =\text { reliabilitas tes secara keseluruhan } \\
p & =\text { proporsi subyek yang benar menjawab } \\
q & =\text { proporsi subyek yang salah menjawab } \\
\sum_{n} p q & =\text { jumlah hasil perkalian antara } p \text { dan } q \\
s & =\text { banyaknya item soal } \\
s & =\text { standar deviasi dari tes }
\end{array}
$$

Uji daya beda

$$
D=\frac{B_{A}}{J_{A}}-\frac{B_{B}}{J_{B}}
$$

$D$ = daya beda

$B_{A}=$ banyaknya peserta kelompok atas yang menjawab soal itu dengan benar

$B_{B}=$ banyaknya peserta kelompok bawah yang menjawab soal itu dengan benar

$J_{A}=$ banyaknya peserta kelas atas

$J_{B}=$ banyaknya peserta kelas bawah 
Uji Taraf kesukaran

$$
P=\frac{B}{J_{S}}
$$

dengan:

$P=$ indeks kesukaran

$B=$ banyaknya siswa yang benar menjawab soal

$J_{s}=$ jumlah seluruh siswa peserta tes

\section{Teknik Analisis Data}

Teknik analisis data pada hasil validitas produk oleh ahli yaitu dilakukan dengan cara menghitung tingkat kelayakan produk secara keseluruhan dengan rumus sebagai berikut:

$$
N P=\frac{R}{S M} \times 100 \%
$$

$$
\text { dengan: }
$$

$N P \quad=$ Nilai persentase

$R \quad=$ Jumlah skor yang diperoleh

$S M=$ Skor maksimum ideal

$\mathrm{I00} \%=$ Bilangan tetap

Nilai persentase dikategorikan sesuai dengan penilaian desain produk yang terdapat pada tabel I berikut ini[8]:

Tabel I. Interval penilaian desain produk

\begin{tabular}{cccc}
\hline No & Nilai Presentasi & Nilai & Predikat \\
\hline I & $86-100 \%$ & A & Sangat Baik \\
2 & $76-85 \%$ & B & Baik \\
3 & $60-75 \%$ & C & Cukup \\
4 & $55-59 \%$ & D & Kurang \\
5 & $<=54 \%$ & E & Kurang Sekali \\
\hline
\end{tabular}

\section{Hasil Penelitian dan Pembahasan}

Tujuan dari penelitian ini adalah untuk mengembangkan produk berupa lembar kegiatan siswa fisika berbasis inkuiry learning untuk mengetahui tingkat kelayakan produk, serta mengukur efektivitas lembar kegiatan siswa fisika hasil dari pengembangan terhadap keterampilan proses siswa. Prosedur pengembangan produk ini melalui tujuh tahap. Produk yang dihasilkan berupa lembar kegiatan siswa fisika berbasis inkuiry learning.

Produk yang dikembangkan berdasarkan pada pendekatan inkuiry learning. Materi yang dipilih adalah gerak lurus. Komponen produk terdiri dari kata pengantar,daftar isi, peta konsep, KI dan KD, sub bab I gerak, jarak dan perpindahan, sub bab II kelajuan, kecepatan dan percepatan, sub bab III GLB dan GLBB, sub bab IV Gerak Vertikal Atas, Gerak Vertikal Bawah, dan Gerak Jatuh Bebas, ulangan harian, dan daftar pustaka. Dari masing-masing sub materi terdiri dari judul, tujuan, problem, hipotesis, kegiatan percobaan, kesimpulan, informasi, dan evaluasi soal. Kegiatan percobaan tersebut terdiri dari alat dan bahan, langkah kegiatan, data kegiatan, dan analisis data.

Produk yang telah dikembangkan kemudian divalidasi oleh ahli. Hasil penilaian seluruh validator diperoleh nilai $83,73 \%$ dengan predikat baik. Sementara penilaian dari masing-masing validator yaitu ahli media diperoleh nilai $87,24 \%$ dengan predikat sangat baik, penilaian ahli materi diperoleh nilai persentase $80,21 \%$ dengan predikat baik. Hasil penilaian ahli tersebut menunjukkan produk layak digunakan sebagai bahan ajar pada kegiatan pembelajaran gerak lurus.

Soal yang terdapat pada evaluasi IV yang terdiri dari 20 soal divalidasi secara empiris oleh siswa kelas X MIA 5 SMA N 4 Yogyakarta dengan jumlah siswa sebanyak 28 siswa, dan diperoleh 16 soal yang valid. Setelah divalidasi soal yang valid di uji reliabilitas, daya beda dan tingkat kesukaran.

Produk yang telah divalidasi kemudian direvisi (revisi desain) dengan mempertimbangkan masukan dan saran dari ahli. Produk hasil revisi kemudian diujicobakan kepada siswa. Uji coba produk dilakukan kepada siswa kelas X MIA 6 SMA N 4 Yogyakarta dengan jumlah siswa sebanyak 29 siswa. Pengujian dilakukan melalui dua tahap. Sebelum $\left(\mathrm{O}_{1}\right)$ siswa melakukan kegiatan pembelajaran tanpa menggunakan lembar kegiatan siswa, dan pada tahap sesudah $\left(\mathrm{O}_{2}\right)$ siswa melakukan kegiatan pembelajaran dengan menggunakan lembar kegiatan siswa hasil pengembangan. Dari hasil uji coba produk yang telah dilakukan kepada siswa diketahui bahwa keterampilan proses siswa meningkat dari sebelum menggunakan produk ke setelah menggunakan produk pengembangan.

Secara klasikal nilai rata-rata sebelum menggunakan produk yaitu 53,10\% dengan predikat sangat kurang. Pada tahap kedua yaitu setelah menggunakan produk diperoleh nilai rata-rata $76,90 \%$ dengan predikat baik. Terdapat peningkatan nilai dari sebelum ke setelah menggunakan produk sebesar 23,8\%. Peningkatan persentase keterampilan proses ini terjadi karena pada produk pengembangan diterapkan pendekatan inkuiry learning, sehingga keterampilan proses siswa dalam melaksanakan kegiatan pembelajaran lebih efektif dan efisien.

Produk akhir dari pengembangan ini merupakan produk hasil dari revisi produk. Produk yang dihasilkan berupa buku lembar kegiatan siswa fisika berbasis inkuiry learning pada pokok bahasan gerak lurus. Melalui lembar kegiatan siswa ini keterampilan proses siswa pada saat kegiatan pembelajaran dapat meningkat. 


\section{Kesimpulan}

Berdasarkan hasil penelitian dan pembahasan, dapat diperoleh kesimpulan sebagai berikut:

I. Dihasilkan produk pengembangan berupa lembar kegiatan siswa fisika berbasis inkuiry learning pada pokok bahasan gerak lurus yang mampu meningkatkan keterampilan proses siswa pada saat kegiatan pembelajaran.

2. Diperoleh produk yang layak digunakan sebagai bahan ajar bagi siswa pada saat kegiatan pembelajaran. Hal ini ditunjukkan dengan nilai yang diperoleh yaitu dari validator sebesar $83,73 \%$ predikat baik.

3. Lembar kegiatan siswa fisika berbasis inquiry learning efektif terhadap peningkatan keterampilan proses siswa. Hal tersebut ditunjukan dengan perolehan nilai rata-rata keterampilan proses siswa secara klasikal meningkat sebesar $23,80 \%$ dari sebelumnya $53,10 \%$ (predikat kurang) menjadi76,90\% (predikat baik).

\section{Kepustakaan}

[1] Handayani. S, FISIKA Untuk SMA dan MA kelas X, Jakarta, Departemen Pendidikan Nasional, 2009

[2] Pribadi. B. A, Model Desain Sistem Pembelajaran, Jakarta, Dian Rakyat, $201 \mathrm{I}$

[3] Prastowo. A, Panduan Kreatif Membuat Bahan Ajar Inovatif, Jogjakarta, DIVA Press, 2013

[4] Ridwan. A, Pengembangan LKS Gerak Lurus Berbasis Gambar Proses Untuk Pembelajaran Fisika di SMA, JURNAL PEMBELAJARAN FISIKA (JPF), 20I4, 3I7-322.

[5] Khoiriyah. N, Pengembangan Bahan Ajar Lembar Kerja Siswa (LKS) Fisika Berbasis Laboratory Training Untuk Pembelajaran Fisika SMA Kelas X Semester I. Skripsi, Yogyakarta, UAD, 2014

[6] Astuti. Y, Pengembangan Lembar Kerja Siswa (LKS) Berbasis Pendekatan Inkuiri Terbimbing Dalam Pembelajaran Kooperatif Pada Materi Kalor, Pendidikan IPA Indonesia, 2013, 88-92.

[7] Sanjaya. W, Strategi Pembelajaran Berorientasi Standar Proses Pendidikan, Jakarta, Rineka Cipta, 2009

[8] Purwanto. N, Prinsip - prinsip dan Teknik Evaluasi Pengajaran, Bandung, Remaja Rosdakarya, 2012

[9] Sugiyono, Metode Penelitian Pendidikan Pendekatan Kuantitatif, Kualitatif, dan R\&D. Bandung, Alfabeta, 2009 